\title{
Ocorrência de infeccção pelo vírus da língua azul em rebanhos bubalinos do Maranhão
}

Helder de Moraes Pereira", Amanda Taylla Lima Silva, Vanessa Evangelista de Sousa

Curso de Medicina Veterinária, Universidade Estadual do Maranhão (UEMA), São Luís, MA, Brasil

*Autor correspondente

e-mail: helderpereirap@yahoo.com.br

\section{Resumo}

A língua azul é uma doença infecciosa, não contagiosa, transmitida por dípteros do gênero Culicóides, sendo amplamente disseminada no Brasil devido às condições de temperatura e umidade do país, fatores que favorecem a multiplicação e perpetuação do vetor no ambiente. O BTV é um vírus pertencente ao gênero Orbivírus. Enfermidade de notificação obrigatória, cujo impacto econômico decorre não apenas de perdas reprodutivas como também restrições comerciais por parte dos países importadores, apesar de pouco relatado acomete também o rebanho bubalino. Um estudo realizado em Nepal, em 2016, mostrou que de 379 búfalos, a presença de anticorpos contra a língua azul foi detectada em mais de 55\% da população. Entretanto, tanto os bovinos quanto os búfalos podem atuar como portadores do vírus, sem apresentarem qualquer forma clínica da doença. Os bubalinos podem atuar como hospedeiros amplificadores assintomáticos. Frente à escassez de dados epidemiológicos sobre a ocorrência de língua azul em búfalos no estado do Maranhão e o perigo de um hospedeiro assintomático, transmitindo e fazendo a manutenção da doença no rebanho, o trabalho visou evidenciar a existência da infecção dentro do rebanho bubalino no estado do Maranhão, a fim de se aplicar medidas eficazes de controle da enfermidade. A amostragem foi estabelecida por conveniência, com base em estudo não probabilístico, proveniente de 16 rebanhos oriundos dos municípios Arari, Matinha, Olinda Nova do Maranhão, Pinheiro, São João Batista, Viana e Vitória do Mearim (Baixada Maranhense). Foram utilizadas 387 amostras de sangue de búfalos (28 machos e 359 fêmeas). A técnica empregada para o diagnóstico sorológico da língua azul em bubalinos foi a imunodifusão em gel de ágar (IDGA), teste padrão para o diagnóstico desta enfermidade. A frequência encontrada foi de 87,3\% (n = 338 ) de animais reagentes e $12,7 \%$ de animais negativos $(n=49)$. Acreditamos que o elevado percentual de animais reagentes nesta pesquisa se deu pelo fato das condições climáticas serem favoráveis à transmissão desta enfermidade. Frente aos dados positivos, e sabendo que a língua azul é uma enfermidade silenciosa, 
torna-se de extrema importância tomar medidas de prevenção como vacinação, controle de importação e quarentena, acompanhada de duas ou três sorologias, e medidas de controle como o diagnóstico rápido, desinfecção rigorosa do ambiente e o controle da população de vetores. Deste modo, concluiu-se que a infecção pelo vírus da língua azul em búfalos do estado do Maranhão é alta. 